\title{
Study of Changes in Currant During Fast Freezing
}

\author{
Serhii Kiurchev ${ }^{1}$ \\ ${ }^{1}$ Dmitry Motornyi Tavria State Agro- \\ technological University, Melitopol, \\ Ukraine \\ serhii.kiurchev@tsatu.edu.ua
}

Taras Hutsol ${ }^{2}$

${ }^{2}$ State Agrarian and Engineering

University in Podilia,

Kamianets-Podilskyi,Ukraine pro-gp@pdatu.edu.ua

\author{
ValentynaVerkholantseva ${ }^{1}$ \\ ${ }^{1}$ Dmitry Motornyi Tavria State Agrotech- \\ nological University, \\ Melitopol, Ukraine \\ valentyna.verkholantseva@tsatu.edu.ua
}

\author{
Iryna Semenyshyna ${ }^{2}$ \\ ${ }^{2}$ State Agrarian and Engineering University \\ in Podilia, \\ Kamianets-Podilskyi,Ukraine \\ dakgps@pdatu.edu.ua
}

\author{
Lyidmila Kiurcheva ${ }^{1}$ \\ ${ }^{1}$ Dmitry Motornyi Tavria State \\ Agrotechnological University, Meli- \\ topol, Ukraine \\ lyidmila2007@ukr.net
}

\begin{abstract}
Frozen berries have a number of undeniable advantages: they do not require additional preparation costs, are almost ready to eat, and most importantly, thanks to modern technologies, they retain almost twice as much nutrients as with other canning methods. Increasingly, there are risks associated with internal and external factors, as well as problems with excess yields that threaten not to sell the product fresh. short shelf life immediately after harvest, which increases the critical dependence on market prices. One of the progressive technological methods of processing fruit and berry products is quick freezing. The use of such freezing gives, first of all, a low degree of product damage, minimally reduces the biological value and taste characteristics, and the use of freezing does not significantly affect the quality of the thawed product.

The main task of an industrial or commercial line for shock freezing of berries is to ensure almost instantaneous preservation of the product, which will retain all its nutritional value and taste. This is usually achieved by rapidly chilling the berries to $-18{ }^{\circ} \mathrm{C}$. By far the best option for extending the shelf life of freshly cooked food is to freeze it quickly. There are various options, but the best known is the freezing technology. For instant freezing without crystallization, it is necessary to provide a temperature of -5 ...$18{ }^{\circ} \mathrm{C}$. Experimental data were obtained during research. The temperature regime of storage of currants with the preservation of quality indicators using a freezing device is also considered. When frozen quickly, the berries should be blown from all sides or literally float in a stream of frosty air of the appropriate temperature.

The duration of this process depends on the type and size of the berries, as well as on the intensity of the cooling air flow. The current direction in the field of research of frozen berries is the preservation of consumer properties of berries after freezing.
\end{abstract}

Keywords - berries, currant, freezing, storage.

\section{INTRODUCTION}

The blast freezing technology, which is similar for any foodstuff, differs in detail for each type of

food. Depending on size, consistency, firmness, maturity, variety and other characteristics, different food products are exposed to different effects of artificial cold using different freezing equipment.

Deep freezing technology for delicate products such as berries requires the use of special refrigeration equipment. Wet and sticky, they easily stick together into lumps, deform even under the influence of their own weight, losing their appearance and consumer qualities. Therefore, freezing of berries can be carried out qualitatively only in fluidizing quick freezers in bulk $[1,2]$.

Currant is a very valuable berry. It contains many vitamins that our body requires every day. The use of black and red currants strengthens the immune system, and vitamin $\mathrm{C}$, which is found in large quantities in black currants, is not destroyed even when frozen [3].

This berry tolerates freezing well if the freezing technology is properly followed. In this case, her physical and chemical properties, as well as taste characteristics, remain unchanged. Such fruits can be stored all winter and longer, until the next harvest appears.

\section{MATERIALS AND METHODS}

In order to preserve the external and internal properties of the berries, the technology is strictly observed. If there is a lot of ice and frost on the berry, then it will lose its taste. And when using such fruits in baking, the dough will get wet and sink.

The choice of berries is important. Crumpled and overripe will stick together into one unattractive mass.

\section{Online ISSN 2256-070X


Unripe, due to the low sugar content, will change color, lose aroma and taste.

Black and red currants are the most attractive as source of ascorbic acid versus other berries and fruits. Pronounced the seasonality of berry production makes you think about ways to save them. One of the most environmentally friendly clean ways -

freezing berries. However, according to biochemical value frozen berries different from fresh ones. After defrosting in berries there is a decrease in the content of ascorbic acids, soluble solids and titratable acids [3,7].

\section{RESULTS AND DISCUSSION}

Before freezing, the berries should be properly prepared. It is necessary to sort them, removing bad berries and removing debris.

Depending on what kind of currants you freeze, there are some peculiarities.

Red currants should be frozen only with twigs. Black can be whole berries $[2,6]$.

After you wash it, you need to spread it on a towel to dry the berries. Drops of water on the berries turn to ice and can destroy the integrity of the skin.

Foodstuffs retain useful substances better if quick freezing is applied to them. Its peculiarity lies in the fact that the liquid contained in the tissues of berries or other product does not have time to expand.

This effect leads to rapid hardening and, as a result, good preservation of the product over a long period of storage. The exact same preservation method should be applied to all types of berries.

Before storage and during storage, we have determined the main indicators of quality. In the course of using the technology, we checked, that is, the following indicators were investigated: mass fraction of sugars, mass fraction of vitamin $\mathrm{C}$, mass fraction of titratable acids, mass fraction of soluble solids [6, 12].

Creation of a fluidization layer of production in the course of its high-temperature processing can be carried out at use of such schemes of executive bodies of cars as: in a fluidization gutter or a tray,in the pneumomechanical system which carries out pulse supply of the refrigerant to a product surface, in a fluidizing rigid container; in the semifluidization conveyor system [4,5,13].

The use of a fluidizing device freezes in the range from $10 \ldots 25^{\circ} \mathrm{C}$ by installing an additional fan with a guide nozzle can improve the movement of the product to be frozen, namely the horizontal movement of the upper layers of the product that do not touch the mesh vehicle, which in turn increases the intensity of heat transfer in the upper layers of the pseudo-liquefied stream and the productivity of the freezing process as a whole [8-11].

In the course of the experiment, a biochemical assessment of the berries was made before freezing and after defrosting (Tab.1)

For each indicator of biochemical assessment, diagrams were plotted (Fig.1-Fig.4).
TABLE 1. BIOCHEMICAL EVALUATION OF BERRIES BEFORE FREEZING AND AFTER DEFROSTINC

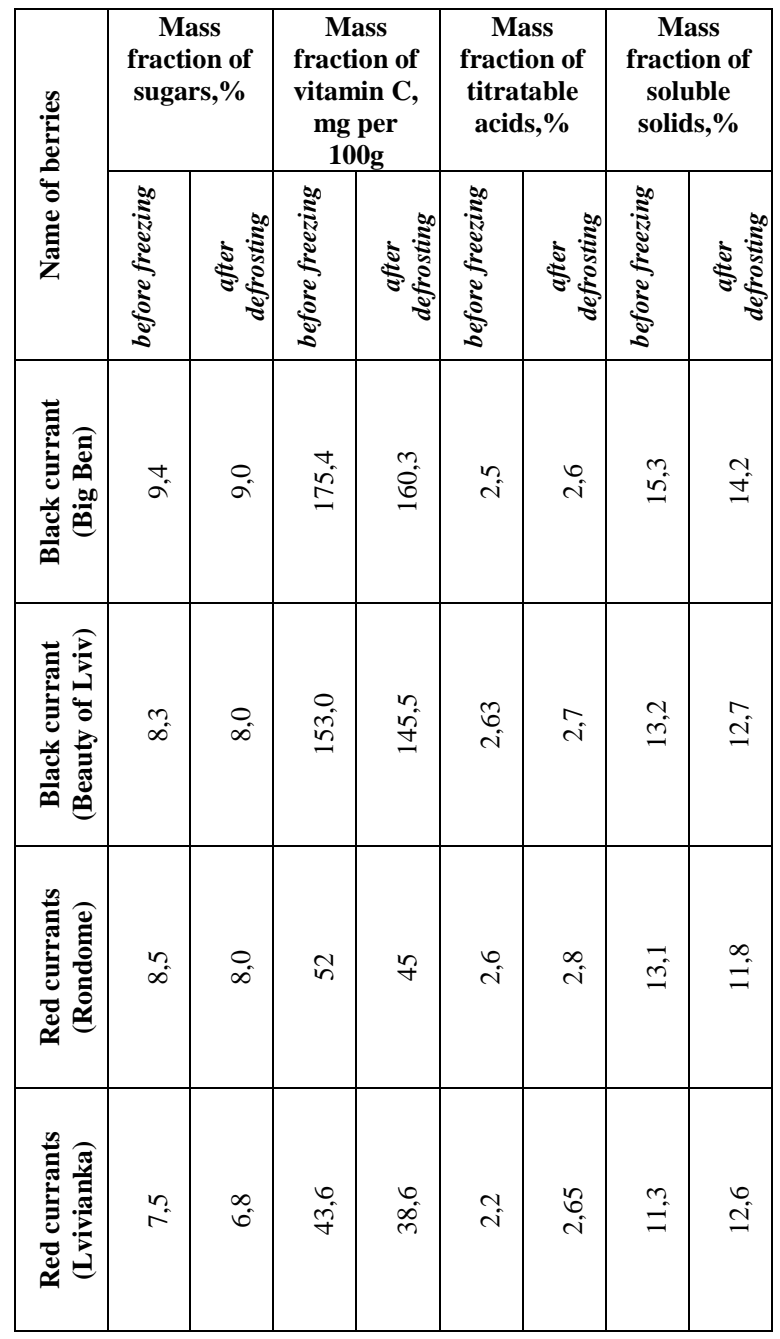

For each indicator of biochemical assessment, charts were built. We offer to consider the mass fraction of sugars for the storage stages for black and red currants in two varieties (Fig.1).

We observe that in both types of currants of different colors, the indicators are normal, but in black currants they are better than in red.

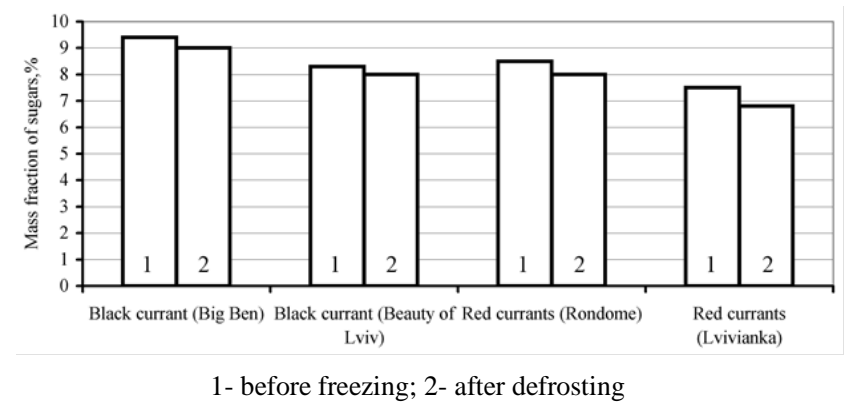

Fig. 1 Mass fraction of sugars depending on the stages of storage currant berries of various sorts

Fig. 2 shows the results for the mass fraction of vitamin $C$ from the storage stages. As we can see, vitamin $C$ in black currant (Big Ben) has significantly decreased, 
and vitamin C in red currant (Lvivianka) has decreased less.

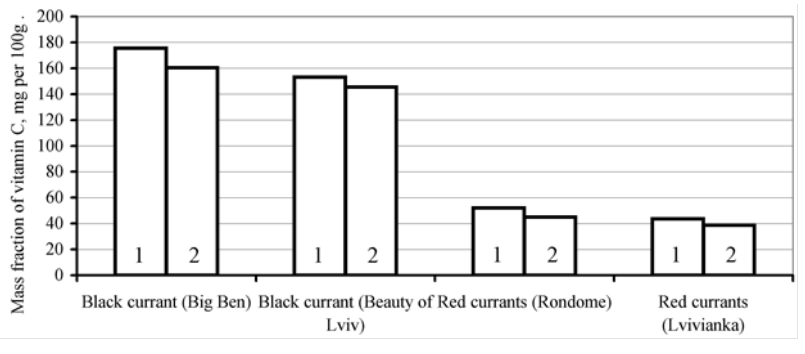

1- before freezing; 2- after defrosting

Fig. 2 Mass fraction of vitamin $\mathrm{C}$ depending on the stages of storage currant berries of various sorts

As for the mass fraction of titratable acids, then the indicator for red currants (Lvivianka) became $0.45 \%$ worse, while for black currants it changed from 0.07 ... $0.1 \%$ (Fig. 3)

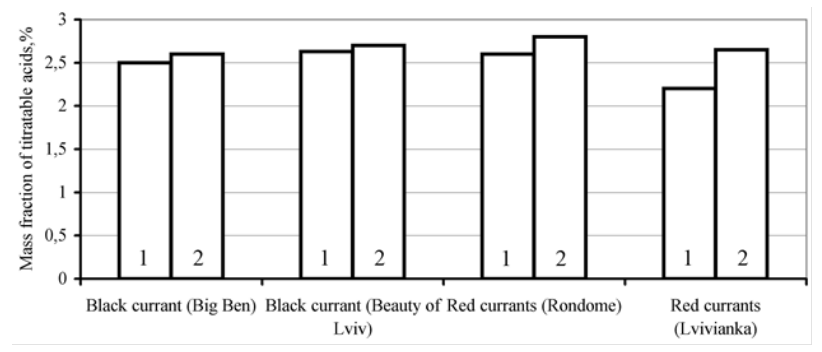

1- before freezing; 2- after defrosting

Fig. 3 Mass fraction of titratable acids depending on the stages of storage currant berries of various sorts

The mass fraction of soluble dry substances from the storage stages was also determined (Fig. 4). In black currant (Beauty of Lviv) it fell slightly by $0.5 \%$, but in red currant (Lvivianka)it increased by $1.3 \%$.

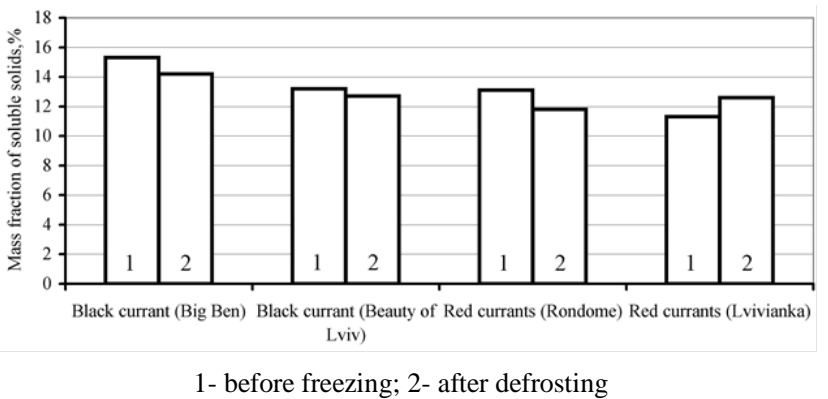

Fig. 4 Mass fraction of soluble solids.depend-ing on the stages of storage currant berries of vari-ous sorts

The free moisture indicator is very important during storage, and even more so during freezing(Fig.5-Fig.8).

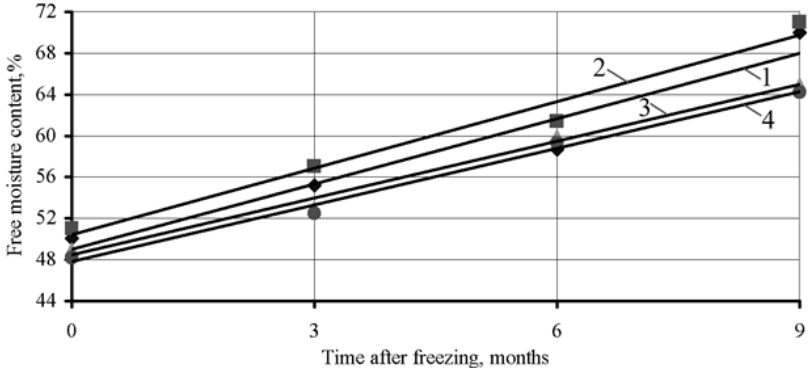

1- Black currant (Big Ben); 2 - Black currant (Beauty of Lviv); 3 Red currants (Rondome); 4 - Red currants (Lvivianka)

Fig.5. Change in free moisture content during storage of currant berries (freezing temperature $\left(-10^{\circ} \mathrm{C}\right)$ )

We observe the most free moisture at a temperature of $\left(-10^{0} \mathrm{C}\right)$ (Fig.5).

With each decrease in temperature in our case, for every $\left(-5^{0} \mathrm{C}\right)$ to a temperature of $\left(-25^{0} \mathrm{C}\right)$, the free moisture content decreased for each variety of currants (Fig.6- Fig.8)

Thanks to these graphs, we can see how the free moisture changes during storage at different temperatures.

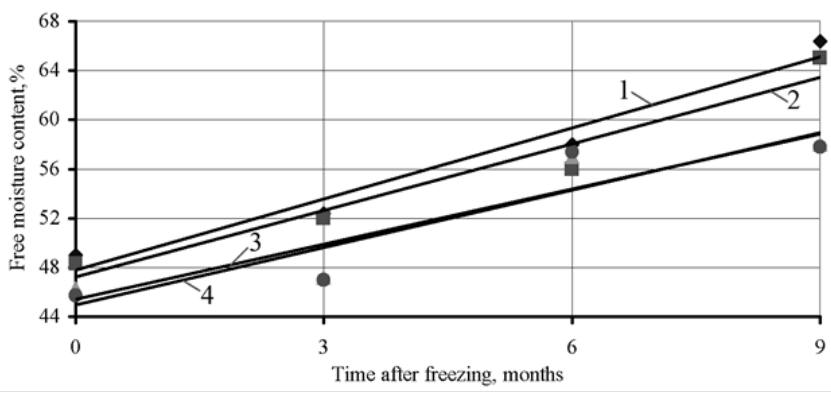

1- Black currant (Big Ben); 2 - Black currant (Beauty of Lviv); 3 Red currants (Rondome); 4 - Red currants (Lvivianka)

Fig.6. Change in free moisture content during storage of currant berries (freezing temperature $\left(-15^{\circ} \mathrm{C}\right)$ )

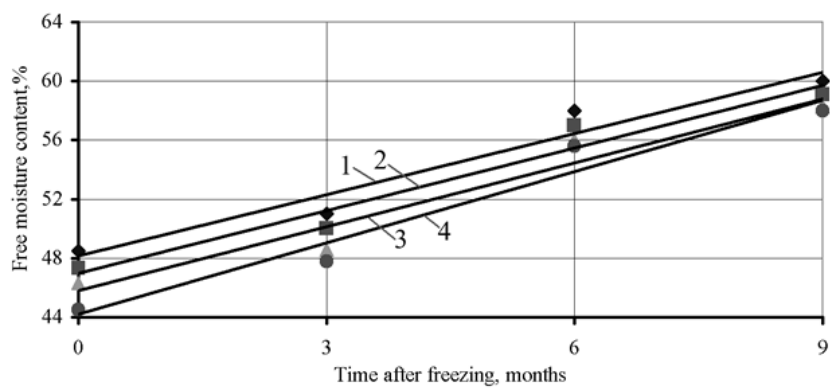

1- Black currant (Big Ben); 2 - Black currant (Beauty of Lviv); 3 Red currants (Rondome); 4 - Red currants (Lvivianka)

Fig.7. Change in free moisture content during storage of currant berries (freezing temperature $\left(-20^{\circ} \mathrm{C}\right)$ ) 


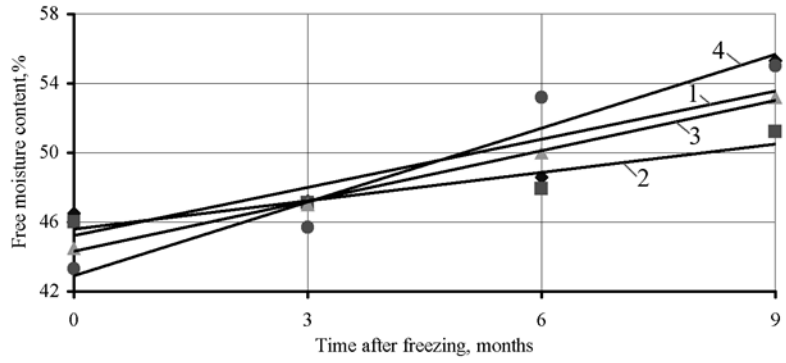

1- Black currant (Big Ben); 2 - Black currant (Beauty of Lviv); 3 Red currants (Rondome); 4 - Red currants (Lvivianka)

Fig.8. Change in free moisture content during storage of currant berries (freezing temperature $\left(-25^{\circ} \mathrm{C}\right)$ )

\section{ACKNOWLEDGMENTS}

We truly thank you for the opportunity to publish our scientific work in your collection of scientific papers.

\section{CONCLUSION}

Shock freezing of currants allows you to preserve the geometry, properties and vitamin composition. After thawing, the product looks fresh and juicy. It is these properties that are so valued, for which special equipment is being developed. It can have different modifications, but in general, the principle of operation remains the same. The design has a cold generator and a chamber, inside which low temperatures are created, leading to instant freezing of food.

The advantages of the technology of using a blast chiller include the following features: with the help of fast freezing, the time for preparing food for storage is significantly reduced; all vitamins and useful components are preserved; the appearance of each berry is also preserved.

\section{REFERENCES}

[1] Yalpachik V.F., Zagorko N.P. and Kiurchev S.V., Eds., Optimization of technology for frozen fruit and vegetable products: Monograph. Melitopol: Vidavnichy booth Melitopolskiy Myskoy Drukarniy, 2018.

[2] Postolski J. and Gruda Z. Freezing of food products. Moskow: Food industry. 1978.
[3] Kiurchev S., Glowacki S. and Verkholantseva V. “An innovative approach for storing berries in the modern”. Innovations in technology and equipment of hotel and restaurant, food and processing industries: international

[4] scientific-practical Internet conference, November 24, 2020. Melitopol: TSATU, 2020. pp. 62-64.

[5] Kiurchev S.V., Verkholantseva V.O., Kiurcheva L.M. and Samoychuk K.O. Goal. ed. prof. V. M. Kyurchev. Vip. 20, vol. 2. Melitopol: TDATU, 2020. pp. 115-123.

[6] Kiurchev S., Verkholantseva V., Yeremenko O. and Al-Nadzhar F. "Research and changes in berries using technology of freezing during storage" Latvia University of Sciences and Techologies Faculty of Engineering. Jelgava, May 2020. pp. 997 -1002.

[7] Fikin A. and Dichev S. The main parameters characterizing the process of fluidization of the layer of fruits and vegetables. Refrigeration № 111976.

[8] Yalpachik V.F. Technological equipment for the processing of products Roslinnstva: Laboratory workshop. Melitopol: Vidavnichy Budynok of Melitopolskiy Miskoy Drukarny, 2017.

[9] Ivanyshyn V., Yermakov S. and, Ishchenko T., Eds. "Calculation algorithm for the dynamic coefficient of vibro-viscosity and other properties of energy willow cuttings movement in terms of their unloading from the tanker”. Proceedings of 6 th International Conference - Renewable Energy Sources, vol. 154, E3S Web of Conferences. 2020.2 pp. 04005. https://doi:10.1051/e3sconf/202015404005

[10] Yermakov S., Hutsol T., Ovcharuk O. and, Kolosiuk I. "Mathematic simulation of cutting unloading from the bunker". Independent journal of management \& amp; production (IJM\&P). Vol. 10, No. 7. 2019. pp. 758-777

[11] Yermakov S., Mudryk K. and Hutsol T., Eds. "The analysis of stochastic processes in unloadingthe energywillow cuttings from the hopper". Environment. Technology. Resources. Rezekne, Latvia. Proceedings of the 12th International Scientific and Practical Conference. Volume III. 2019. pp. 249-252, https://doi:10.17770/etr2019vol3.4159

[12] Samoychuk K.O., Kiurchev S.V. and Yalpachik V.F., Eds. "Innovative technologies and equipment of the industry". Processing of crop products: workshop manual. Melitopol: Publishing and printing center "Lux", 2020.

[13] Tryhuba A., Hutsol T. and Glowacki S., Eds. "Forecasting Quantitative Risk Indicators of Investors in Projects of Biohydrogen Production from Agricultural Raw Materials”. Processes 2021, 9, 258. https://doi.org/10.3390/pr9020258

[14] Tryhuba A, Hutsol T. and Tryhuba I, Eds. "Risk Assessment of Investments in Projects of Production of Raw Materials for Bioethanol”. $\quad$ Processes. 2021; 9(1):12. https://doi.org/10.3390/pr9010012 